\title{
Türkiye'de Kovid 19 Pandemi Sürecine Bağlı Uzaktan Eğitimin Almanca Öğretimine Etkisi
}

\author{
Fatma Karaman (D), Muğla
}

https://doi.org/10.37583/diyalog.1030771

$\ddot{O} z$

Kovid 19 pandemi sürecinin başlamasıyla Türkiye'de üniversitelerdeki her bölüm, derslerini sahip oldukları uzaktan eğitim olanakları çerçevesinde sürdürmek zorunda kalmıştır. Beklenmeyen bu durum, eğitim sürecinde birçok öğretim alanında olduğu gibi Almanca öğretiminde de birçok problemi beraberinde getirmiştir. Bu bağlamda bu çalışmanın amacı pandemi sürecine bağlı olarak uzaktan eğitimin Almanca eğitimine etkilerini Kovid 19 pandemi süreci ve kısıtlamalara ilişkin genel görüşler, alınan eğitimin uzaktan olmasına ilişkin olumlu ve olumsuz görüşler, teknolojik donanım, öğretim etkinlikleri, materyal boyutu, etkileşim, ölçme ve değerlendirme boyutu ve uzaktan eğitim sürecine ilişkin öneriler olmak üzere sekiz tema altında, Almanca öğretmenliği lisans programında öğrenim görmekte olan öğrencilerin deneyimleri ve görüşleri doğrultusunda araştırmaktır. Bu amaca ulaşmak için nitel araştırma deseni kapsamında olgubilim yöntemi kullanılmıştır. Çalışmanın araştırma grubu Muğla Sıtkı Koçman Üniversitesi Eğitim Fakültesi Almanca Öğretmenliği lisans Programında öğrenim gören öğrencilerden oluşmaktadır. Almanca öğretmeni adaylarının uzaktan eğitime ilişkin görüşlerinin belirlenmesi amacıyla veri toplama tekniklerinden biri olan yarı yapılandırılmış görüşme tercih edilmiştir. Araştırmanın tüm verileri çevrimiçi ortamda videokonferans yoluyla yapılan görüşmelerden elde edilen verilerden oluşmaktadır. Görüşme tekniğiyle elde edilen verilerin analiz edilmesinde betimsel analiz kullanılmıştır.

Araştırma sonucunda genel olarak uzaktan eğitimin günlük yaşama ve eğitim hayatına olumsuz etkilerinin daha fazla olduğu sonucuna ulaşılmıştır. Elde edilen bulgulardan Almanca öğretmenliği programındaki alan derslerinin uzaktan eğitime uygun olmadığı, uzaktan eğitim yönteminin 4 temel dil becerisini geliştirmede yeterli olmadığı; ancak uzaktan eğitim sürecinin az da olsa alıcı becerileri geliştirdiği; üretimsel becerileri ise geliştirmediği anlaşılmaktadır.

Anahtar Sözcükler: Pandemi, Kovid 19, Yabancı Dil Öğretimi, Almanca Öğretimi, Uzaktan Eğitim.

\section{Abstract}

The Effect of Distance Education on German Teaching Due to the Covid-19 Pandemic Process in Turkey

With the start of the Covid-19 pandemic, every department in universities in Turkey had to continue their courses within the framework of their distance education opportunities. This unexpected situation has brought along many problems in teaching German, as well as, in many teaching areas in the education process. In this context, the aim of this study is to research the effects of distance education on German education depending on the pandemic process, under eight themes, including general views on the Covid19 pandemic process and restrictions, positive and negative opinions about distance education, 
technological equipment, teaching activities, material dimension, interaction, measurement and evaluation dimension, suggestions for the educational process. In order to achieve this aim, the phenomenology method was used within the scope of the qualitative research design. The research group of the study consists of students studying at Muğla Sttkı Koçman University, Faculty of Education, German Language Teaching Undergraduate Program. Semi-structured interview, which is one of the data collection techniques, was preferred in order to determine the views of German teacher candidates on distance education. All data of the research consists of data obtained from interviews made via videoconference in the online environment. Descriptive analysis was used to analyze the data obtained by the interview technique.

As a result of the research, it has been concluded that the negative effects of distance education on daily life and education life are more in general. According to the results, it is understood that the field courses in the German teaching program are not suitable for distance education, and the distance education method is not sufficient to develop four basic language skills; however, the distance education process slightly improved the receptive skills; it did not develop productive skills.

Keywords: Pandemic, Covid-19, Foreign Language teaching, German Teaching, Distance Education. 


\section{EXTENDED ABSTRACT}

Many political, social, economic, sociological and health-related phenomena in the world affect education greatly. The epidemic disease phenomenon that started to be experienced in 2020, which is related to health is among the abocementioned. As it is known, the Covid 19 virus, which first observed in the city of Wuhan in China and then have spreaded to rest of the world including Turkey, and it has been decided to take a break from face-to-face education and switch to distance education. As a matter of fact, every department in universities, like other school levels, had to continue their courses within the framework of the distance education opportunities they had. This unexpected situation has brought along many problems in teaching German as well as in many teaching areas in the education process. In this context, the aim of this study is to research the effects of distance education on German education depending on the pandemic process, under eight themes, including general views on the Covid 19 pandemic process and restrictions, positive and negative opinions about distance education, technological equipment, teaching activities, material dimension, interaction, measurement and evaluation dimension, suggestions for the educational process.

Semi-structured interview was preferred in order to determine the views of German teacher candidates on distance education. Descriptive analysis was used to analyze the data obtained by the interview technique.

The data obtained in the study were gathered under eight themes: general views on the Covid 19 pandemic process and restrictions, positive and negative views on distance education, technological equipment, teaching activities, material dimension, interaction, measurement and evaluation dimension, and suggestions on the distance education process. It has been concluded that the theoretical courses are effective, but the applied courses that require active participation are not suitable for distance education. The materials used in distance education are not sufficient for students to understand the subject. The marjority of the participants stated that the lecturers only taught the lessons based on slides and emphasized that they experienced a oneway, boring, and educational process that had no educational value. The lack of interactive education is observed.

As a result of the research, it has been concluded that the negative effects of distance education on daily life and education life are more in general. According to the findings, it is understood that the field courses in the German teaching program are not suitable for distance education, and the distance education method is not sufficient to develop 4 basic language skills; however, the distance education process slightly improved the receptive skills not the productive ones. Research generally shows that developing technological infrastructure and equipment cannot replace interactive learning environments. While the advantages of distance education were emphasized in many studies conducted before the pandemic process (Bozavli 2017; Furat 2016; Genç İlter 2009; Hanbay 2002; Kartal 2005; Karaman 2019); In the distance education studies conducted during the pandemic process (Genç / Gümrükçüoğlu 2020; Ak vd. 2020; Türkmen vd. 2020; Can 2020), the striking point is that distance education cannot replace the usual learning environments. In this study, in which the description of the problems in teaching German in distance education and the presentation of solutions were examined, it was concluded that distance education is not suitable for foreign language teaching. Participants wished to be vaccinated, to socialize, to start face-to-face education, to make the lessons interactive, to develop materials for distance education, to have cameras on during the lesson, to improve the infrastructure, to provide equal opportunities, and to give some lessons remotely when face-to-face education was started. Homework was the most preferred measurement tool 
in the distance education process. In general, it is understood that the validity of measurement tools is low. It was stated that the participants passed the courses more easily and got higher grades during the distance education period. Due to the fact that it is not possible for students to accommodate collectively during the pandemic process, each department has not made it possible to implement face-to-face measurement and evaluation. In order to ensure the reliability of measurement and evaluation within the scope of blended education, a suitable environment should be provided for face-to-face examinations. This process should be handled in two ways in terms of instructors and students. Because faculty members had to continue their lessons with a method they were not accustomed to. In order to increase efficiency, course materials suitable for distance education should be prepared. 


\section{Giriş}

Dünya üzerinde yaşanan siyasal, toplumsal, ekonomik, sosyolojik ve sağlığa ilişkin birçok olgunun eğitim üzerinde önemli etkileri vardır. Bu etkilerden biri de sağlıkla ilgili olan 2020 yılında yaşanmaya başlayan salgın hastalık olgusudur. Bilindiği gibi ilk olarak Çin'in Wuhan kentinde başlayan ve daha sonra tüm dünyada görülmeye başlanan Kovid 19 virüsünün, Türkiye'de görülmesiyle birlikte yüz yüze eğitime ara verilerek uzaktan eğitime geçilme kararı alınmıştır. Nitekim diğer okul kademeleri gibi üniversitelerdeki her bölüm de derslerini sahip oldukları uzaktan eğitim olanakları çerçevesinde sürdürmek zorunda kalmıştır. Beklenmeyen bu durumun, eğitim sürecinde birçok öğretim alanında olduğu gibi Almanca öğretiminde de pek çok problemi beraberinde getirdiği düşünülmektedir.

Yabanc1 dil öğretiminin amacı öğrencinin dinleme, konuşma, okuma ve yazma olmak üzere dört temel dil becerilerinde kendini ifade edebileceği yeterliliği kazanmasını sağlamaktır (MEB 2006). Bu amacın gerçekleşmesi için öğretim etkinliklerinin merkezinde öğrencinin olabileceği öğrenme ortamları gerekmektedir. Bu öğrenme ortamlarında bulunması gereken önemli özelliklerden biri de öğrencinin uygulama yapabileceği, yabancı dilde yaşantı kazanabileceği niteliğe sahip olmasıdır. Dolayısıyla bu durum uzaktan eğitim sürecinde Almanca öğretimi kapsamında değerlendirildiğinde, amaçların ne kadar yerine getirilebildiğini araştırmak ve yabancı dil öğretimine uzaktan eğitimin yansımalarını betimleyerek sürece katkı sağlamak adına önem arz etmektedir. Bu süreçte birçok eğitim kurumu uzaktan eğitim alt yapısının olmaması veya altyapısı olsa da kurumların daha önce bu konuda yeterli hazırlık yapmaması nedeniyle birçok problemle karşılaşmıştır (Telli Yamamoto / Altun 2020: 30). Türkiye'de Atatürk Üniversitesi, Anadolu Üniversitesi ve İstanbul Üniversitesi gibi birçok üniversite 2020 yılındaki pandemi salgınından önce de bazı lisans veya önlisans programları ve dersleri uzaktan eğitim yöntemiyle öğrencisine sunmaktayd1. Pandemi sürecinin uzaması ve bu süreçte yaşanan belirsizlikler nedeniyle Türkiye'deki diğer birçok üniversite de uzaktan eğitim merkezleri kurarak uzaktan eğitim alt yapılarını daha da güçlendirmek durumunda kalmıştır.

Türkiye'de 2019-2020 bahar döneminin mart ayında ani bir şekilde uzaktan eğitime geçilmiştir. İlk etapta çoğu üniversitede sisteme ders notları, slayt, makale ve pdf dosyası gibi öğretim materyallerini yükleme şeklinde yürütülen bu süreç 2020-2021 güz ve bahar döneminde uzaktan canlı ders biçiminde sürdürülmeye başlanmıştır (Ak vd. 2020: 893; Genç / Gümrükçüoğlu 2020: 405). Dolayısıyla pandemi sürecinden önce alternatif bir yöntem olarak kullanılan uzaktan eğitimin, 2019-2020 ve 2020-2021 eğitim ve öğretim yıllarında zorunlu olarak kullanılan tek yöntem olması, birçok sıkıntıyı da beraberinde getirmiştir. Beklenmeyen bir durum olması nedeniyle gerek öğretim üyeleri gerekse de öğrenciler bu süreçte birçok problemle karşılaşmışlardır. Uzaktan eğitim süreci sadece öğretim aşamasında değil; ölçme ve değerlendirme aşamasında da gerçekleşmiştir ve bu aşamada da bazı sıkıntılarla karşılaşılmıştır (Bozkurt 2020; Özalkan 2021; Sarı 2020). Bu bağlamda çalışmanın amacı pandemi sürecine bağlı uzaktan eğitimin, Almanca Öğretmenliği lisans programına etkilerini sadece dil öğretimi değil, aynı zamanda meslek bilgisi ve pedagoji dersleri kapsamında 
Muğla Sitkı Koçman Üniversitesi örneğinde araştırmaktır. Böylece pandemi sürecine bağlı uzaktan eğitimin olumlu veya olumsuz etkileri belirlenecektir. Çalışmada Almanca öğretmeni adaylarının deneyimleri ve görüşleri doğrultusunda Kovid 19 pandemi süreci ve kısıtlamalara ilişkin genel görüşler, alınan eğitimin uzaktan olmasına ilişsin olumlu veya olumsuz görüşler, teknolojik donanım, öğretim etkinlikleri, ders materyalleri, etkileşim, ölçme, değerlendirme boyutu ve uzaktan eğitim sürecine ilişkin öneriler olmak üzere sekiz tema altında düzenlenmiştir. Almanca Öğretmenliği lisans programına salgın sürecinin etkileri öğrenci görüşleri doğrultusunda araştırılmıştır.

\section{Yöntem}

Almanca Öğretmenliği lisans programındaki Almanca eğitimine salgın sürecinin etkilerinin öğrenci görüşleri doğrultusunda araştıran ve etik kurul onayı Sosyal ve Beşeri Bilimler Araştırmaları Etik Kurulundan 210124 numaralı başvuru ile alınan bu çalışmada nitel araştırma deseni kapsamında olgubilim (fenomenoloji) yöntemi kullanılmıştır. Olgubilim "farkında olduğumuz ancak derinlemesine ve ayrıntılı bir anlayışa sahip olmadığımız olgulara odaklanmaktadır" (Yıldırım / Şimşek 2018: 69). Bu yöntemde araştırma konusuna yönelik yaşantıları ortaya çıkarmak için bireyle görüşmeler yapılır (Büyüköztürk ve diğerleri 2013: 20).

\section{Araştırma Grubu}

Çalışmanın araştırma grubu ölçüt örnekleme yöntemi kullanılarak belirlenmiştir. Ölçüt örnekleme yöntemine göre araştırmanın yapılacağı grup için önceden bazı ölçütler belirlenir ve bu ölçütlere uygun olan katılımcılar çalışmaya dâhil edilir (Yıldırım / Şimşek 2008). Buna göre bu çalışmada da katılımcıların belirlenmesinde bazı ölçütler dikkate alınmıştır. Bu ölçütler; katılımcıların en az bir yıl boyunca derslerini uzaktan eğitim yöntemiyle sürdürmesi, Almanca Öğretmenliği lisans programında öğrenim görmeleri, çalışmaya gönüllü katılmaları, görüşmelerin video-konferans yoluyla yapılması için gerekli araca sahip olmalarıdır. Katılımcıların aritmetik not ortalamaları dikkate alınarak düşük, orta ve yüksek not ortalaması olan öğrenciler çalışmaya dâhil edilmiştir. Bu araştırmada, Muğla Sıtkı Koçman Üniversitesi Eğitim Fakültesi Alman Dili Eğitimi Anabilim Dalında öğrenim görmekte olan 15 öğrenciye ulaşılmıştır. Araştırmanın katılımcılarına ilişkin bilgiler aşağıdaki tablo 1' de sunulmuştur. 


\begin{tabular}{cccc}
\hline Katılımeı sırası & Cinsiyet & Yaş & Sınıf \\
\hline K-1 & Erkek & 19 & 1 \\
K-2 & Kadın & 19 & 1 \\
K-3 & Kadın & 20 & 1 \\
K-4 & Kadın & 22 & 2 \\
K-5 & Kadın & 20 & 2 \\
K-6 & Kadın & 21 & 2 \\
K-7 & Kadın & 21 & 2 \\
K-8 & Erkek & 23 & 3 \\
K-9 & Erkek & 22 & 3 \\
K-10 & Kadın & 22 & 3 \\
K-11 & Kadın & 23 & 3 \\
K-12 & Kadın & 24 & 4 \\
K-13 & Kadın & 23 & 4 \\
K-14 & Kadın & 26 & 4 \\
K-15 & Kadın & 25 & 4 \\
& & & \\
\hline
\end{tabular}

Tablo 1: Katılımcılara Yönelik Demografik Bilgiler

Araştırmaya gönüllü olarak katılacak öğrencilere e-posta yolu ile bilgi ve onam formları iletilmiştir.

\section{Veri Toplama Aracı ve Verilerin Toplanması}

Almanca öğretmeni adaylarının uzaktan eğitime ilişkin görüşlerinin belirlenmesi amacıyla veri toplama tekniklerinden biri olan yarı yapılandırılmış görüşme tercih edilmiştir. Bu tekniğin tercih edilme nedeni katılımcıların deneyimlerine, algılarına ve görüşlerine ilişkin derinlemesine bilgi almaktır (Yıldırım / Şimşek 2008: 120). Bu amaca ulaşmak için araştırmacı tarafindan görüşmelerde kullanılması için görüşme soruları hazırlanmıştır. Görüşme soruları hazırlanırken araştırmacının uzaktan iki dönem ders vermesine bağlı olarak ders esnasında edindiği tecrübelerden ve alan yazında uzaktan eğitim sürecine ilişkin yapılan çalışmaların bulgu ve sonuçlarından faydalanılarak görüşme soruları şekillendirilmiştir. Daha sonra yabancı dil alan uzmanı iki kişiden uzman görüşü alınarak sorular nihai hale getirilmiştir. Buna göre uzaktan eğitimin öğretim etkinlikleri, donanım, öğretim materyali, etkileşim, ölçme ve değerlendirme boyutlarını gözler önüne seren 14 soru hazırlanmıştır. Katılımcılara sorulan sorular aşağıdaki gibidir; 
1. Covid-19 pandemisi süreci ve kısıtlamalara ilişkin genel düşünceleriniz/ görüşleriniz nelerdir? Pandeminin hayatınıza etkileri nasıl olmuştur? Açıklayınız.

2. Aldığınız eğitimin uzaktan olmasına ilişkin genel görüşleriniz nelerdir?

3. Uzaktan eğitimde kullanılan teknolojik donanıma ilişkin deneyimleriniz nelerdir?

4. Ev ortamı derslere motivasyonunuzu nasıl etkiledi?

5. Uzaktan eğitimin olumlu yanları sizce nelerdir?

6. Uzaktan eğitimin olumsuz yanları sizce nelerdir?

7. Uzaktan eğitimde kullanılan ders materyallerine ilişkin görüşleriniz nelerdir?

8. Uzaktan eğitim ders sürelerine ilişkin görüşleriniz nelerdir?

9. Uzaktan eğitim derslerinde öğretim elemanı ve öğrenci etkileşiminin yeterliliğine ilişkin görüşleriniz nelerdir?

10. Uzaktan eğitimde ölçme ve değerlendirme süreçlerine ilişkin görüş ve deneyimleriniz nelerdir?

11. Öğretim elemanının uzaktan eğitime yönelik yeterliliğine ilişkin görüşleriniz nelerdir?

12. Uzaktan eğitimin Almanca dört temel dil becerisine katkısı nedir?

13. Uzaktan eğitimin ders çalışma sürecinde öz-yönetim becerilerine etkisi nasıl olmuştur?

14. Önerileriniz/ dilekleriniz nelerdir?

Görüşmeler 24.05.2021-04.06.2021 tarihleri arasında araştırmacı tarafından katılımcıların ders saatleri dışında belirlenmiş olan gün ve saatte yapılmıştır. Her bir görüşme yaklaşık olarak 35 dakika sürmüştür.

\section{Verilerin Analiz Edilmesi}

Görüşme tekniğiyle elde edilmiş olan veriler görüşme soruları temel alınarak oluşturulan verilerin temalar altında birleştirilerek sistemli bir şekilde sunulduğu betimsel analiz yöntemiyle (Yıldırım / Şimşek 2008) analiz edilmiştir. Çalışmada elde edilen veriler katılımcıların izni alınarak Zoom aracılığıyla yapılan görüşmelerin kaydedilmesi ile elde edilmiştir. Zoom üzerinden elde edilen kayıt dosyalarının her biri etik kurallar dikkate alınarak K1, K2, K3 ve K4 biçiminde adlandırılmıştır. Daha sonra kayıt dosyaları araştırmacı tarafından dikkatlice dinlenerek olduğu gibi Word belgesine yazılmıştır. Kayıt dosyalarının yazıya dökülmesinde katılımcıların konuşma dilindeki ifade biçimleri düzeltilerek yazı dilindeki doğru biçimleri ile aktarım yapılmıştır. Örneğin; "gelcem" ifadesi düzeltilerek "geleceğim" biçiminde yazılmıştır. Ses dosyalarının Word dosyasına aktarım sürecinde hata olabileceği ihtimali göz önünde bulundurularak kayıtlar tekrar dinlenip kontrol edilmiştir. Tüm dosyalar toplanarak sayfa numarası verilmiştir. Yazıya geçirilen dosyaların çıktıları alınmıştır. Daha sonra 
kategori anahtarı formu düzenlenmiştir. Katılımcıların her birinin her bir soruya verdiği yanıtlar birkaç kez okunarak verilen yanıtlar uygun olan kategorilere dönüştürülmüştür. $\mathrm{Bu}$ işlem aşaması diğer bütün sorulara uygulanmıştır. Oluşturulan temalar altında kategoriler ve bu kategorilere bağlı alt kategoriler oluşturularak frekansları hesaplanmıştır.

Elde edilen tüm veriler yorumlandıktan sonra belirlenen temalar altında kategoriler ve alt kategoriler düzenlenmiştir. Daha sonra temalar, kategoriler ve alt kategorilerde uyumsuzluk olabileceği düşünülerek birkaç kategori ve alt kategori yeniden isimlendirilmiştir, tekrarlanan bazı kategoriler birleştirilmiştir, anlamsız olanlar ise çıkarılmıştır. Bu süreçte tema, kategori ve alt kategoriler konusunda yabancı dil eğitiminde uzman olan bir araştırmacının görüşleri alınmıştır. Daha sonra tema, kategori ve alt kategoriler belirlenmiştir ve elde edilen veriler sistematik bir şekilde sunulmuştur.

Araştırmanın geçerlik ve güvenirliğini sağlamak amacıyla teyit edilebilirlik, aktarılabilirlik ve inandırıcılık aşamaları gerçekleştirilmeye çalışılmıştır. Teyit edilebilirlik aşamasında alan uzmanından yardım alınmıştır. Bu amaç için uzman ve araştırmacı birbirlerinden haberdar olmadan kategori anahtarı yardımıyla görüşme dökümlerini değerlendirmişlerdir. $\mathrm{Bu}$ aşamada beş katılımcının dökümleri okunup incelenmiştir. Ulaşılan sonuç Miles ve Huberman'ın (1994) geliştirdiği [(Görüş birliği/ Görüş birliği + Görüş ayrılığı) x 100] formülü ile hesaplanmıştır. Teyit incelemesi neticesinde en düşük $\% 80$, en yüksek ise $\% 100$ ve ortalama $\% 96.06$ olduğu belirlenmiştir. Bulguların sunumunda katılımcıların yanıtlarına ilişkin doğrudan alıntılara yer verilerek aktarılabilirlik yapılmıştır. İnandırıcılığı sağlamak için katılımcılara görüşme dökümleri iletilmiş, beyanlarının doğru yazılıp yazılmadı̆̆ sorulmuştur. Katılımcılar görüşme dökümlerinde beyanların kendilerine ait olduğunu teyit etmişlerdir.

\section{Bulgular}

$\mathrm{Bu}$ bölümde çalışmada elde edilen veriler, Kovid 19 pandemi süreci ve kısıtlamalara ilişkin genel görüşler, alınan eğitimin uzaktan olmasına ilişkin olumlu ve olumsuz görüşler, teknolojik donanım, öğretim etkinlikleri, materyal boyutu, etkileşim, ölçme ve değerlendirme boyutu ve uzaktan eğitim sürecine ilişkin öneriler olmak üzere sekiz tema altında toplanarak sunulmaktadır.

Aşağıda Kovid 19 pandemi süreci ve kısıtlamalara ilişkin genel görüşlerin yer aldığı tema tablolaştırılmıştır. 


\begin{tabular}{|c|c|c|c|}
\hline Tema & Kategoriler & Alt kategoriler & $\mathrm{f}$ \\
\hline $\begin{array}{l}\text { TEMA 1- Kovid } 19 \\
\text { pandemi süreci ve } \\
\text { k1sitlamalara ilişkin } \\
\text { genel görüşler }\end{array}$ & $\begin{array}{l}\text { 1.1 Günlük yaşama } \\
\text { İlişkin görüşler }\end{array}$ & $\begin{array}{l}\text { 1.1.1 Sosyalleşememe } \\
\text { 1.1.2.Özgürlüğün kısıtlanması } \\
\text { 1.1.3. Kimseye ihtiyaç duymama, } \\
\text { yalnızlaşma } \\
\text { 1.1.4. İçine kapanma } \\
\text { 1.1.5. Enerjinin azalması } \\
\text { 1.1.6. Bazı şeylerin değerinin } \\
\text { unutulması } \\
\text { 1.1.7. Fırsat } \\
\text { 1.1.8. İnsanlara tahammülsüzlük } \\
\text { 1.1.9.Psikolojinin bozulması } \\
\text { 1.1.10. Sıkılma } \\
\text { 1.1.11. Yeni hobiler edinme }\end{array}$ & $\begin{array}{l}9 \\
3 \\
1\end{array}$ \\
\hline & $\begin{array}{l}\text { 1.2.Eğitim hayatına } \\
\text { ilişkin genel görüşler }\end{array}$ & $\begin{array}{l}\text { 1.2.1. Zor bir sürȩ̧ } \\
\text { 1.2.2. Verimsiz } \\
\text { 1.2.3.Düşük Konsantrasyon } \\
\text { 1.2.4.Zaman bolluğu } \\
\text { 1.2.5. Almancanın ilerlememesi } \\
\text { 1.2.6.Düşük motivasyon } \\
\text { 1.2.7. Akademik gerileme } \\
\text { 1.2.8. Araştırmaya teşvik } \\
\text { 1.2.9. Derse katılımın olmaması } \\
\text { 1.2.10. Suistimale açı olması } \\
\text { 1.2.11. Alt yapı yetersizliği }\end{array}$ & $\begin{array}{l}5 \\
9 \\
7 \\
3 \\
11 \\
5 \\
8 \\
3 \\
6 \\
6 \\
7\end{array}$ \\
\hline
\end{tabular}

Tablo 2: Kovid 19 pandemi süreci ve kısıtlamalara ilişkin genel görüşler

Katılımcılar Kovid 19 pandemi sürecine ilişkin görüşlerini günlük hayat ve eğitim hayatı olmak üzere iki açıdan dile getirmişlerdir. Günlük hayata olumsuz etkileri sosyalleşememe, özgürlüğün kısıtlanması, kimseye ihtiyaç duymama, yalnızlaşma, içine kapanma, enerjinin azalması, bazı şeylerin değerinin unutulması, insanlara tahammülsüzlük, psikolojinin bozulması, sıkılma biçiminde ifade edilirken; bu sürece ilişkin olumlu görüşler ise firsat ve yeni hobiler edinme biçiminde belirtilmiştir. Eğitim hayatı açısından olumsuz etkileri zor ve verimsiz bir süreç olması, öğrenci konsantrasyonunun ve motivasyonunun düşük olması, Almanca bilgisinin ilerletilememesi, akademik anlamda gerileme, derse katılımın olmamas1, alt yap1 yetersizliği, sürecin suistimale açık olması biçiminde kategorilendirilmiştir. Eğitim açısından zamanın bol olması ve araştırmaya teşvik edilen bir süreç olması ise sürecin 
olumlu etkileri biçiminde kategorilendirilmiştir. Genel olarak bu sürecin günlük ve eğitim hayatına olumsuz etkilerinin daha fazla olduğu anlaşılmaktadır. Katılımcıların söz konusu görüşlerinden birkaç örnek aşağıda yer almaktadır.

K6: "Hem eğitim hem de sosyal açıdan çok yoksunum. Evden çıkamadım. Kendimi geliştiremedim. Illk dönemler dersler asenkron olduğu için hocalarla konuşma firsatımız da olmadı. Bir şey öğrenemedim açıkçası. Psikolojik yönden beni olumsuz etkiledi. Her günüm aynıydı. Bugün günlerden ne denildiğinde bilmiyordum."

K11: "Sosyalleşememek olumsuz etkiledi. Çok sıkıldım. Kendime yeni hobiler edindim keman ve gitar öğrenmeye başladım. Resim yapmaya başladım. Disiplinimiz kalmadı bu süreçte. Derslere 3. 5 kişi katılıyordu. Sinavlarda ödev verildiğinde kopyala yapıştır yapıyorlar kimse bir şey ögrrenmiyor açıkçası. Derse girip sessize alıyorlar sonra. Ciddiye alınmadı dersleri güzel ögrenemedik. Karşıda sizi kontrol eden biri olmadı̆̆ içcin de suistimal edildi."

K5: "Olumsuz yanı ise bazı şeylerin değerini kaybetmeye başladık mesela yorulmayı unuttuk, topluca bir şeyler yapmayı unuttuk, çalışmayı unuttuk. Rahata alıştık. Artık insanlarla iletişim kurmaya takatimiz de kalmadl. En ufak şeylerde sinirlenmeye başlyyoruz. Bunun gibi bazı şeyleri yitirmeye başladık bence. Anlatma becerimiz insan ilişkileriyle gelişebilir. Mesela biz sunumlar yapıyoruz. Bunun içinde iletişim becerimizin iyi olması gerekir fakat bu süreçte bu becerimiz gelişmedi."

Yukarıda direkt verilen öğrenci ifadelerinden anlaşıldığı gibi pandemi sürecine bağlı kısıtlamalar öğrencileri sosyal, eğitsel, psikolojik ve bedensel açıdan olumsuz etkilemişsir. Buna karşın bu kısıtlamaların yeni hobi edinme gibi olumlu etkileri olduğu da belirtilmiştir.

Aşağıda alınan eğitimin uzaktan olmasına ilişkin genel görüşlerin yer aldığı tema tablolaştırılmıştır.

\begin{tabular}{|c|c|c|c|}
\hline Tema & Kategoriler & Alt kategoriler & $F$ \\
\hline \multirow[t]{2}{*}{$\begin{array}{l}\text { TEMA 2- Alınan } \\
\text { eğitimin uzaktan } \\
\text { olmasına ilişsin } \\
\text { olumlu olumsuz } \\
\text { görüşler }\end{array}$} & $\begin{array}{l}\text { 2.1.Uzaktan eğitimin } \\
\text { olumlu yönleri }\end{array}$ & $\begin{array}{l}\text { 2.1.1.Aileyle daha çok zaman geçirme } \\
\text { 2.1.2.Kayıttan tekrar izleyebilme } \\
\text { 2.1.3. Öğrenciye çok zaman kalması } \\
\text { 2.1.4. Kendine zaman ayırabilme } \\
\text { 2.1.5. Yorucu olmaması } \\
\text { 2.1.6. Ekonomik } \\
\text { 2.1.7. Zaman kısıtlamasının olmaması } \\
\text { 2.1.8. Arkadaşlarından not isteme } \\
\text { sıkıntısının olmaması } \\
\text { 2.1.9.Mekân sınırının olmaması } \\
\text { 2.1.10.Yeni sistemlerin geliştirilmesi }\end{array}$ & $\begin{array}{l}3 \\
3\end{array}$ \\
\hline & $\begin{array}{l}\text { 2.2.Uzaktan eğitimin } \\
\text { olumsuz yönleri }\end{array}$ & $\begin{array}{l}\text { 2.2.1.Derse girmek istemeyen için } \\
\text { bahanenin çok olması } \\
\text { 2.2.2. Sınavlarda yardımlaşma }\end{array}$ & 5 \\
\hline
\end{tabular}




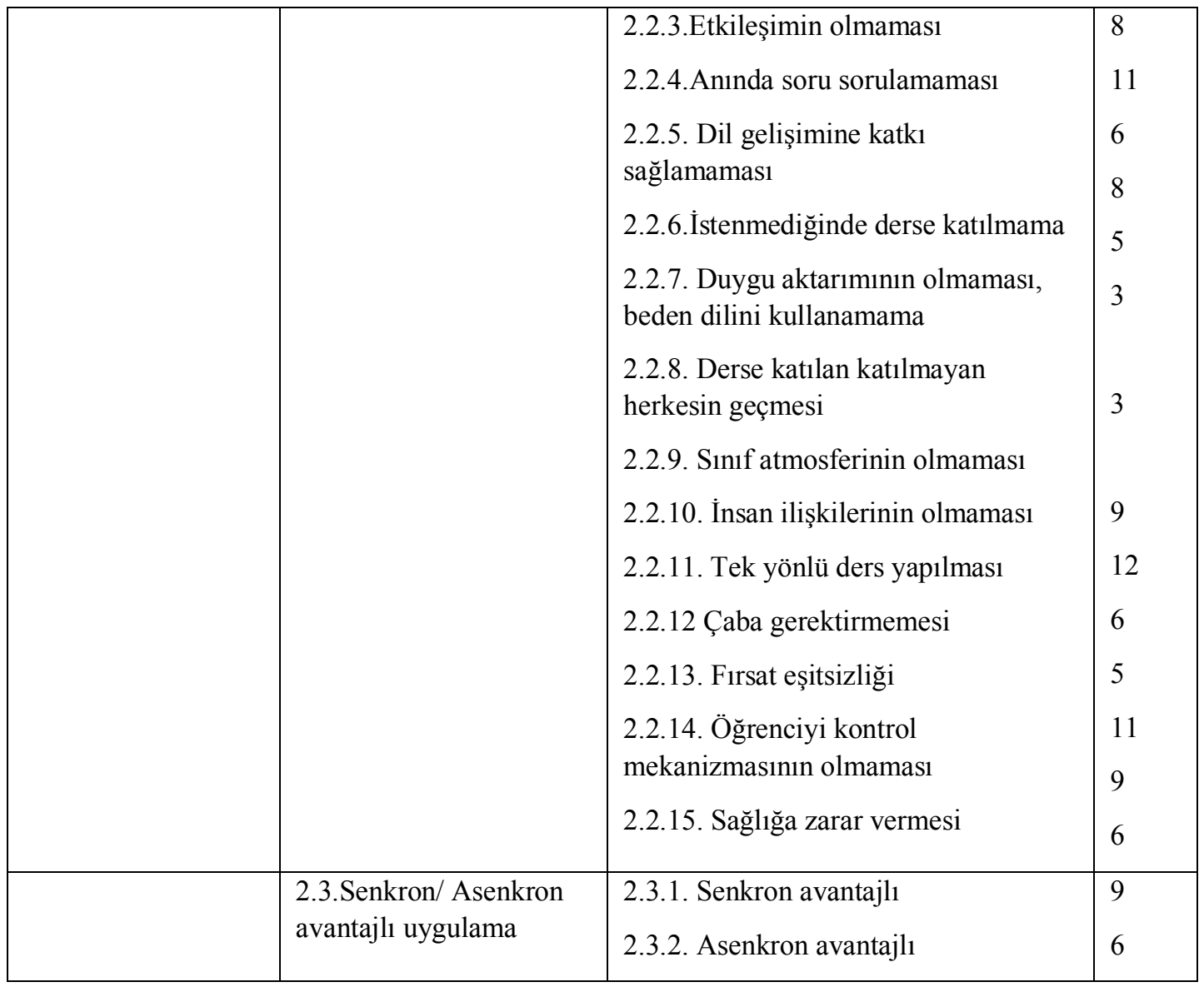

Tablo 3: Alınan eğitimin uzaktan olmasına ilişkin genel görüşler

Alınan eğitimin uzaktan olmasına ilişkin katılımcılar hem olumlu hem de olumsuz görüş belirtmişlerdir. Olumlu görüşler aileyle daha çok zaman geçirme, kayıttan tekrar izleyebilme, öğrenciye çok zaman kalması, kendine zaman ayırabilme, yorucu olmaması, ekonomik, zaman kısıtlamasının olmaması, arkadaşlarından not isteme sıkıntısının olmaması, mekân sınırının olmaması, yeni sistemlerin geliştirilmesi olarak belirlenmiştir. Olumsuz görüşler; derse girmek istemeyen için bahanenin çok olması, sınavlarda yardımlaşma, etkileşimin olmaması, anında soru sorulamaması, dil öğrenimine katkı sağlamaması, öğrenci istemediğinde derse katılmama lüksünün olması, duygu aktarımının olmaması, derse katılan, katılmayan herkesin dersi geçmesi, sınıf atmosferinin olmaması, insan ilişkilerinin olmaması, tek yönlü ders yapılması, firsat eşitsizliği, kontrol mekanizmasının olmaması ve sağlığa zarar vermesi biçiminde belirtilmiştir. Genel olarak öğrenciler uzaktan eğitimin olumsuz yönünün daha fazla olduğunu vurgulamışlardır. Katılımcıların söz konusu görüşlerinden bazıları, aşağıdaki örneklerde sunulmaktadır:

K3: "Olumlu yanlarını saymada biraz zorlandım sanırım. Dersi kaçırdiğımızda daha sonra kayıttan izleyebiliyoruz. Olumsuz yani ögrenci istediğinde derse kendini kapatabiliyor. Köyde yaşayanlar için internet problemi oluyor ve kardeşi olanlar için ise derse girmede sikıntı çekmeleri çok olası.” 
K6: "Olumlu yani evde olduğumuz için pek masrafim olmadı açıkçası. Ailelerimiz bu dönemde çalışamadığ için maaşlarını hep eksik aldılar. Bu dönemde okulda olsaydım maddi açıdan çok zorlanırdım. Ben normalde erken kalmayı sevmiyorum uzaktan olduğu için istediğim saatte kalkıp istediğim saatte ders girdim. Dersleri tekrar izleme firsatım oldu anlamadiğım konuları. Yorulmadık ve enerji harcamadı."

Katılımcılardan dokuzu sınıf ortamına yakın olması, anında dönüt alma, motivasyonun daha yüksek olması nedenlerine bağlı olarak senkron uygulamanın daha avantajlı olduğunu belirtirken; altısı istenildiği zaman kaydı izleyebilme, işte çalışma, telafi edilebilir olduğu için asenkron uygulamanın daha avantajlı olduğunu ifade etmişlerdir.

Teknolojik donanıma ilişkin genel görüşlerin yer aldığı temanın tablosu aşağıda yer almaktadır:

\begin{tabular}{|c|c|c|c|}
\hline Tema & Kategoriler & Alt kategoriler & $\mathrm{F}$ \\
\hline \multirow{4}{*}{$\begin{array}{l}\text { TEMA } 3 \text { Teknolojik } \\
\text { donanım }\end{array}$} & \multirow{2}{*}{$\begin{array}{l}\text { 3.1.Uzaktan eğitimin alt } \\
\text { yapısına sahip olma }\end{array}$} & 3.1.1.Sahibim & 11 \\
\hline & & 3.1.2.Sahip değilim & 3 \\
\hline & \multirow{2}{*}{$\begin{array}{l}\text { 3.2. DYS'de sikınt1 } \\
\text { çekme durumu }\end{array}$} & 3.2.1. Sıkıntı çektim & 6 \\
\hline & & 3.2.2.Sıkıntı çekmedim & 9 \\
\hline & \multirow{2}{*}{$\begin{array}{l}\text { 3. 3.Tekonolojik } \\
\text { yeterliliğe sahip olma }\end{array}$} & 3.3.1. İyi düzeyde sahibim & 10 \\
\hline & & 3.3.2. Orta düzeyde sahibim & 5 \\
\hline & \multirow{2}{*}{$\begin{array}{l}\text { 3.4. Uygun bir ev } \\
\text { ortamına sahip olma }\end{array}$} & 3.4.1. Evet & 10 \\
\hline & & 3.4.2. Hayır & 5 \\
\hline
\end{tabular}

Tablo 4: Teknolojik donanıma ilişkin genel görüşler

Yukarıdaki tabloda görüldüğü gibi 11 katılımcı uzaktan eğitim altyapısına sahipken; 3 katılımcı sahip değildir. Muğla Sıtkı Koçman Üniversitesi uzaktan eğitim sürecinde ders yönetim sisteminde Adobe Connect uygulamasını kullanmıştır. Katılımcılara Muğla Sıtkı Koçman Üniversitesinin kullandığı sisteme ilişkin sıkıntı çekip çekmedikleri sorulmuştur. 9 katılımcı sistemi kullanma konusunda sıkıntı çekmediklerini belirtirken, 6'sı sıkıntı çektiğini ifade etmiştir. Katılımcıların teknolojik yeterliklerine ilişkin görüşleri ise genel olarak olumlu yöndedir. Görüşmelerde katılımcıların ev ortamının uzaktan eğitim için uygunluğuna yönelik görüşleri de alınmıştır. 10 katılımcı uygun bir ev ortamına sahip olduğunu, 5 katılımcı sahip olmadığını belirtmiştir. Katılımcıların söz konusu görüşleri birkaç örnek bağlamında aşağıda gösterilmektedir:

K4: "En başta sistemde donmalar ve bağlantı sorunları yaşıyordum. Sonradan bu sisteme hocalarımız da alıştı. Yönetim de alıştı sonraki dönemlerde daha kolay iletişim kurabildik. Artık çok nadir bağlantı sorunu oluyor. "

K2: "Evet sahiptim, çünkü evde annemle ben yaşıyorum. Iyiydi. Çünkü annem çalışlyordu ben de kendi odamda derslere girebiliyordum. Ama ben tek başına çalışmayı seven biri değilim arkadaşlarım olsa daha iyi ders dinler ve çalışırdım. Tek olduğumda hemen konsantrem bozuluyor." 
K7: "Evet ev ortamina sahiptim. Ailem bu konuda çok hassas davrandl. Ama yine de aklım dağıllyordu. Çünkü bazen evde biz kedi de besliyoruz. Ve onlarla bazen ben ilgilenmek zorunda kalıyordum dersin ortasında ondan dolayı bazen kopukluklar yaşıyordum."

Katılımcılar, üniversitenin uzaktan eğitimde kullandığı sisteme ilişkin başlangıçta sisteme alışılamaması nedeniyle sorun yaşadıklarını, ancak ilerleyen süreçte sisteme alıştıklarını ifade etmişlerdir. Bunun yanı sıra derslere katılabilmek için ailelerinin kendilerine uygun bir ortam sunmaya özen gösterdiklerini belirtmişlerdir.

Öğretim etkinliklerine ilişkin genel görüşlerin yer aldığı tema aşağıdaki tabloda sunulmaktadır:

\begin{tabular}{|c|c|c|c|}
\hline Tema & Kategoriler & Alt kategoriler & $\mathrm{F}$ \\
\hline \multirow[t]{5}{*}{$\begin{array}{l}\text { TEMA 4- Öğretim } \\
\text { etkinliklerine ilişkin } \\
\text { genel görüşler }\end{array}$} & $\begin{array}{l}\text { 4.1.Destekleme için } \\
\text { yapılan çalışmalar }\end{array}$ & $\begin{array}{l}\text { 4.1.1. Test çözme } \\
\text { 4.1.2.Youtube'dan konu izleme } \\
\text { 4.1.3. Videoları tekrar izleme } \\
\text { 4.1.4. Google'dan arama } \\
\text { 4.1.5. Almanca dizi film izlemek } \\
\text { 4.1.6. Başka üniversitelerden not alma } \\
\text { 4.1.7. Hiçbir şey }\end{array}$ & $\begin{array}{l}3 \\
3 \\
1 \\
5 \\
3 \\
3 \\
5\end{array}$ \\
\hline & $\begin{array}{l}\text { 4.2.Bölüm derslerinin } \\
\text { uzaktan eğitime } \\
\text { uygunluğuna ilişkin } \\
\text { genel görüşler }\end{array}$ & $\begin{array}{l}\text { 4.2.1.Uzaktan eğitime uygun değil } \\
\text { 4.2.2. Uzaktan eğitime uygun }\end{array}$ & $\begin{array}{l}11 \\
4\end{array}$ \\
\hline & $\begin{array}{l}\text { 4. 3.Verim alınan } \\
\text { dersler }\end{array}$ & $\begin{array}{l}\text { 4.3.1.Almancanın yapısı } \\
\text { 4.3.2.Okuma becerileri } \\
\text { 4.3.3.Yazma becerileri } \\
\text { 4.3.4.Eğitim Felsefesi } \\
\text { 4.3.5. Eğitim Sosyolojisi } \\
\text { 4.3.6. Almanca öğretim programları } \\
\text { 4.3.7. Dil öğrenme stratejileri }\end{array}$ & $\begin{array}{l}5 \\
5 \\
2 \\
3 \\
3 \\
5 \\
8\end{array}$ \\
\hline & $\begin{array}{l}\text { 4.4. Verim alınmayan } \\
\text { dersler }\end{array}$ & $\begin{array}{l}\text { 4.4.1. Sözlü iletişim becerileri } \\
\text { 4.4.2.Uygulamalı dersler } \\
\text { 4.4.3.Alman Edebiyatı } \\
\text { 4.4.4. Öğretmenlik uygulaması } \\
\text { 4.4.5. Slaytla anlatılan dersler }\end{array}$ & $\begin{array}{l}8 \\
11 \\
6 \\
12 \\
11\end{array}$ \\
\hline & $\begin{array}{l}\text { 4.5. Dil becerilerine } \\
\text { katkısı }\end{array}$ & $\begin{array}{l}\text { 4.5.1. Okuma } \\
\text { 4.5.2. Yazma } \\
\text { 4.5.3. Dinleme } \\
\text { 4.5.4. Konuşma }\end{array}$ & $\begin{array}{l}9 \\
5 \\
10 \\
0\end{array}$ \\
\hline
\end{tabular}




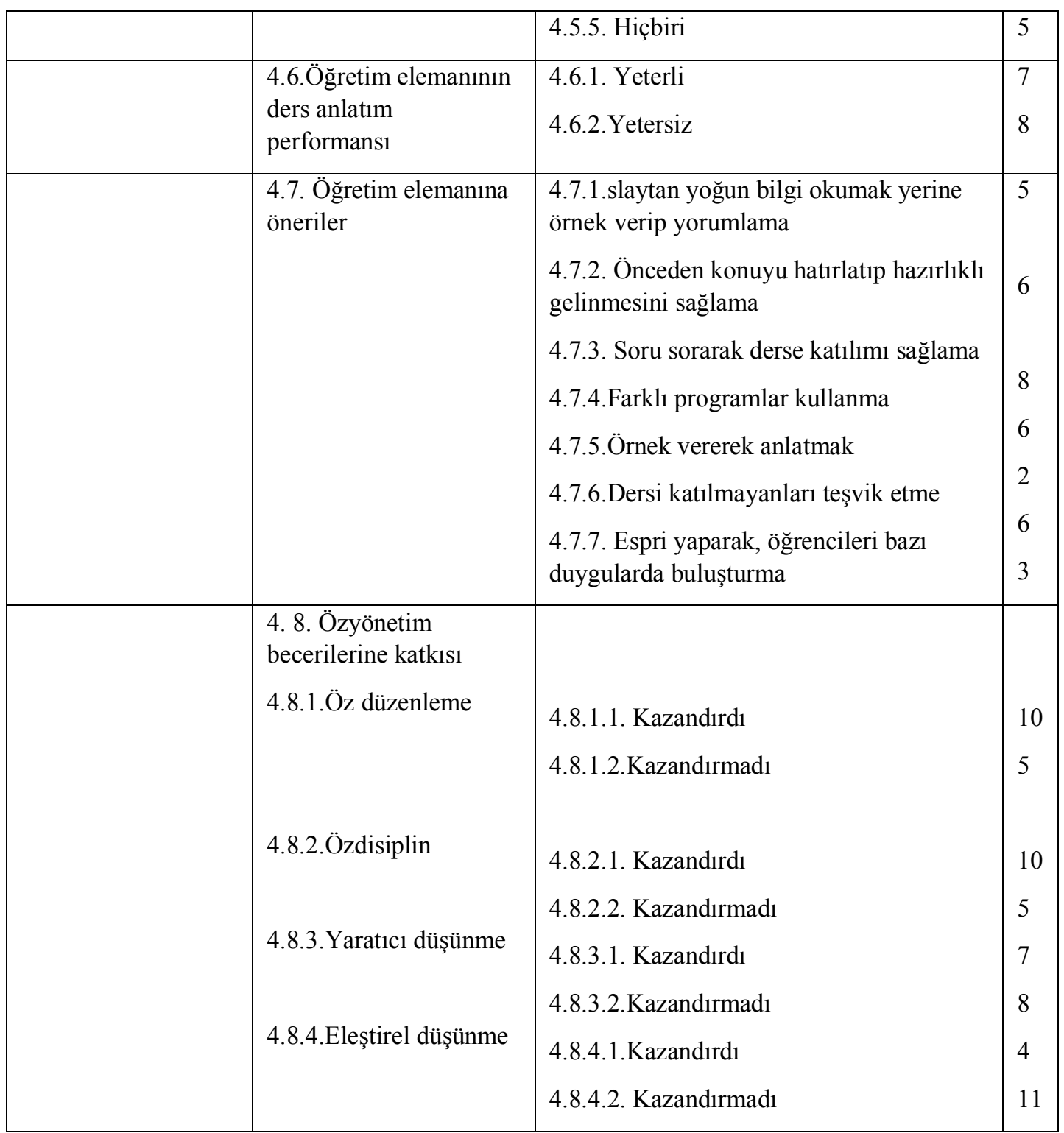

Tablo 5: Öğretim Etkinliklerine İlişkin Genel Görüşler

3 katılımcı test çözerek, 3 katılımcı Youtube'dan konu izleyerek, 1 katılımcı videoları tekrar izleyerek, 5 katılımcı Google'dan araştırarak, 3 katılımcı Almanca dizi veya film izleyerek, 3 katılımcı başka üniversitelerden ders notları alarak uzaktan eğitimdeki dersleri desteklediklerini belirtirken, 5 katılımcı ise dersleri desteklemek için bir şey yapmadığını ifade etmiştir. Yine 11 katılımcı bölüm derslerinin uzaktan eğitime uygun olmadığ1 görüşündeyken, 4 katılımcı uygun olduğunu düşünmektedir. Katılımcılar bu düşüncelerini aşağıdaki örneklerde görüleceği şekilde dile getirmişlerdir:

K7: "Konuşma dersi için uygun olduğunu söyleyemem çünkü ses gitmiyor, kimisinin mikrofonu olmuyor. Yüz yüzenin verdiği o şey olmuyor. Mimik ve jestlerimiz görünmediği için. Ortak dersler için uzaktan eğitim uygun diğer hiçbir dersimiz için uygun olduğunu düşünmüyorum."

K9: "Sadece eğitim derslerinden verim aldım maalesef çünkü dilimi geliş̧irmem için konuşmam gerekiyor ama bu olmadl." 
Katılımcılar Almancanın yapısı, okuma, eğitim felsefesi, eğitim sosyolojisi, Almanca öğretim programları, dil öğrenme stratejileri derslerinden verim aldıklarını belirtirken; sözlü iletişim becerileri, yazma becerileri, uygulamalı dersler, Alman edebiyatı, öğretmenlik uygulaması, slaytla anlatılan derslerden verim almadıklarını ifade etmişlerdir. Genel olarak teorik derslerden katılımcıların verim aldıkları; uygulamalı ve etkinliğe dayalı derslerde verim almadıkları anlaşılmıştır. Katılımcıların bu konudaki görüşlerinden iki tanesi aşağıdaki örneklerde sunulmaktadır:

K2:"Bence Almanca derslerinin yüz yüze olması gerekiyordu çünkü diller konuşularak ögrenilebilir. Böyle bilgisayar üzerinden ögrenmek çok oluyor. Ama eğitim bilimleri dersleri uzaktan da olabilir. Sözlü iletişim becerileri dersi uygun değildi uzaktan eğitime çünkü o derste bizim sürekli konuşmamız gerekiyor o derste ve konuşma şansımız olmadı. Almancanın yapısı ve okuma becerileri uygundu."

K4: "Uygulamalı dersler için uygun değil. Almanca ögretim programları dersinden verim aldım. Bazı derslerimizde de sadece ödev olduğu için çok da katkısı olmadı bana. Mesela Alman edebiyatı daha çok ödev olarak geçti derste genelde ödevlere odaklandım."

Diğer bir soruda katılımcılara uzaktan eğitimin dil becerilerine katk1 sağlayıp sağlamadığı sorulmuştur. 9 katılımcı okuma becerisine, 10 katılımcı dinleme becerisine, 5 katılımcı ise yazma becerisine katkı sağladığını ifade ederken, 5 katılımcı hiçbir beceriye ve 15 katılımcı da konuşma becerisine katkı sağlamadığını belirtmiştir. Genel olarak uzaktan eğitim sürecinin az da olsa alıcı becerileri geliştirirken, üretimsel becerileri geliştirmediği anlaşılmaktadır. Katılımcıların görüşlerini şu şekilde dile getirmiştir:

K5: "Okuma ve dinlemeye en çok katkı sağladı bence. Çünkü evde olduğumuz için dersleri dinlemek zorunda kallyoruz. Kulak dolgunluğu için iyi oldu ama cevap verme açısından yani konuşma açısından kötü oldu. Kendimizin bir şeyler yazabilme becerisini kaybettik bence çünkü ödev verildiğinde de internetten bakarak yazdı̆̆ımız için kendi başımıza cümle kurmadığımız için yazma becerimiz geriledi."

K1: Bence katkı sağlamıyor özellikle dil ögretimi için söylemek gerekirse asla bilgisayardan dil ögrenilemiyor bence diğer dersler için bir şey söyleyemem belki bir nebze iyidir. Ama yabanct dil için gerçekten uzaktan olmaması gerektiğini düşünüyorum.

7 katılımcı öğretim elemanının ders anlatım performansını yeterli bulurken, 8 katılımcı ise yetersiz bulmuştur. Katılımcılar söz konusu görüşlerini aşağıdaki gibi ifade etmişlerdir:

K6: "Yeterli olduğunu düşünüyorum Çünkü daha başka yapllacak bir şey yok. “

K8: "Sürekli slayttan okumak bunu ben de indirip okuyabilirim ama hem slayttan okuyup hem de açıklamalı bir şekilde slayttan bağımsız örnek vererek açıklama yapınca o zaman dinleyesim geliyor. "

Araştırmada "Öğretim elemanının yerinde olsaydınız dersi nasıl yürütürdünüz?" sorusu katılımcılara yöneltilerek öğrencilerin beklentileri belirlenmeye çalışılmıştır. Katılımcılar öğretim elemanının ders anlatımına ilişkin slayttan yoğun bilgi okumak yerine örnek verip yorumlama, önceden konuyu hatırlatıp hazırlıklı gelinmesini sağlama, soru sorarak derse katılımı sağlama, farklı programlar kullanma, örnek vererek 
anlatmak, derse katılmayanları teşvik etme, espri yaparak, öğrencileri bazı duygularda buluşturma gibi önerilerde bulunmuşlardır. Katılımcıların söz konusu görüşleri aşağıdaki örneklerde görülmektedir:

K2: "Slayttı direk okumak yerine anlatarak dersi yapması arada espri yapmast ya da Chat'ten soru sorduğumuzda onları da takip ederek dersi anlatmal. Mesela soru soruyoruz görmüyor okumuyor. Bizimle iletişim kurarak bizi de derse katarak işlemeli.

K3: "Slaytlara alternatif olarak konunun yapısına göre oyunlar yapılabilir. Görsel olarak gördüklerimizi daha çok hatırladiğımız için görseller konulabilir. Slaytta söyleyeceğimiz her şeyi yazmamalıyı öncelikle. İpucu gibi kisa kisa hatırlatmalarla söylenecekler zenginleştirilerek konunun hoca tarafindan anlatılması daha etkili olur. Öğrenciye soru sorularak derse etkin katılım sağlanmalıdır."

K6: "Sadece slaytlara bağlı kalınabiliyordu bazı derslerde hocalar. Onlar da bilgisayart kullanma konusunda belki de iyi olmadıkları için o şekilde slaytta bağlı kalarak dersi işliyorlardı. Bu konuda da üniversitenin hocalara bilgisayar kullanımı konusunda eğitim vermesi iyi olacaktır. Çünkü farklı bir programla ders işlenmedi, farklı bir yol izlenmedi. “

10 katılımcı uzaktan eğitim sürecinin öz düzenleme ve öz disiplin becerisini geliştirdiğini, 5 katılımcı ise geliştirmediğini belirtmiştir. 7 katılımcı bu sürecin yaratıcı düşünme becerisini geliştirdiğini, 8 katılımcı ise geliştirmediğini belirtmiştir. 4 katılımcı eleştirel düşüncenin gelişimine uzaktan eğitimin katkı sağladığı görüşündeyken, 11 katılımcı eleştirel düşüncenin gelişime katkı sağlamadığı görüşündedir. Katılımcıların söz konusu görüşlerinden birkaç örnek aşağıda yer almaktadır:

K2: "Ders saatlerime göre günümü düzenliyordum o nedenle öz düzenleme alışkanlı̆̆ kattı. Alışkanlıklarımda değişiklik yarattı. Geceleri çok geç uyumaya başladım. Yaratıcı düşünme becerisi kattı. Resim yapıyorum artık küçük bir kitap yazdım. Asla kendimden beklemediğim bir hareket."

K4: "Evet kesinlikle gelişti kendimi daha çok planlayabildim bu süreçte mesela "ne kadar ders çalışacağım, ne zaman başlayacağım ve bitireceğim” gibi düzenlemelerimi yaptım. Belli bir program çerçevesinde ilerleyebildim. Daha önce disiplinli bir şeyleri yürütemiyordum ama şimdi bu alışkanlıkları kazandım. Geliştirdi. Artık bir çerçeveden bakmıyorum daha farkı açılardan bakabiliyorum olaylara."

K6: "Pek kattlğg söylenemez çünkü yüz yüze eğitimde disiplinli bir öğrenciydim ama uzaktan eğitimde ben de saldım. Bu rahatlık beni gevşetti. Dersleri geçerim diye kasmadım. Yüz yüzeyken daha çok kasıyordum kendimi. Disipline olamadım uzaktan eğitimde. Bazı konularda geliştirdi mesela staj dersinde ögrencileri nasıl derse katabilirim bu sistemde dersi nastl daha verimli yaparım diye daha yaratıcı düşündüm."

K8: "Aksine bana göre daha disiplinsiz oldum. Yüz yüzeyken uyku düzenimiz, ders saatlerimiz çok çok iyiydi. Hayır gelişstirmedi."

K13: "Evet katkı sağladı. Kendimi ders saatlerime göre disipline ettim. Hayatıma düzen getirdi. Eleştirel düşünmeye katkı sağlamadı maalesef. Derste sadece sunuş yolu yöntemini kullandı̆̆ için gelişmedi. “

Yukarıdaki katılımcı ifadelerinden anlaşıldığı gibi uzaktan eğitim süreci bazı katılımcılara öz düzenleme, öz disiplin becerilerini kazandırırken, bazıları için ise bu süreç plansız bir yaşam biçimini beraberinde getirmiştir. 
Aşağıda uzaktan eğitim ders materyallerine ilişkin genel görüşlerin yer aldığı tema tablolaştırılmıştır:

\begin{tabular}{|c|c|c|c|}
\hline $\begin{array}{l}\text { Tema } \\
\text { TEMA } 5 \text { Uzaktan } \\
\text { eğitim ders } \\
\text { materyallerine ilişkin } \\
\text { görüşler }\end{array}$ & Kategoriler & Alt kategoriler & $\mathrm{F}$ \\
\hline \multirow[t]{4}{*}{$\begin{array}{l}\text { TEMA } 5 \text { Uzaktan } \\
\text { eğitim ders } \\
\text { materyallerine ilişkin } \\
\text { görüşler }\end{array}$} & $\begin{array}{l}\text { 5.1.DYS'ye yüklenen } \\
\text { ders materyallerinden } \\
\text { yararlanma durumu }\end{array}$ & $\begin{array}{l}\text { 5.1.1. Yararlandım } \\
\text { 3.1.2. Yararlanmadım }\end{array}$ & $\begin{array}{l}11 \\
4\end{array}$ \\
\hline & $\begin{array}{l}\text { 5.2.Konuyu öğrenmede } \\
\text { yeterliliği }\end{array}$ & $\begin{array}{l}\text { 5.2.1. Yeterli } \\
\text { 5.2.2. Yetersiz }\end{array}$ & $\begin{array}{l}6 \\
9\end{array}$ \\
\hline & $\begin{array}{l}\text { 5.3. Sadece slayta bağlı } \\
\text { kalınması }\end{array}$ & $\begin{array}{l}\text { 5.3.1.ögrretici değil } \\
\text { 5.3.2. olumsuz bir durum } \\
\text { 5.3.3.S1kıcı } \\
\text { 5.3.4. Tek yönlü }\end{array}$ & $\begin{array}{l}5 \\
3 \\
5 \\
6\end{array}$ \\
\hline & $\begin{array}{l}\text { 5.4. Slayta alternatif } \\
\text { öneriler }\end{array}$ & $\begin{array}{l}\text { 5.4.1.Kendinden bir şey katmalı, } \\
\text { yorumlamalı } \\
\text { 5.4.2. Espri yapmalı } \\
\text { 5.4.3.Etkileşim kurmalı } \\
\text { 5.4.4.Soru sormalı } \\
\text { 5.4.5.Söylenecek her şey slaytta } \\
\text { yazılmamalı } \\
\text { 5.4.6. Örneklendirmeli, benzetme } \\
\text { yapmalı } \\
\text { 5.4.7. Farklı programlar kullanılmalı } \\
\text { 5.4.8. Video ve film verilmeli }\end{array}$ & $\begin{array}{l}6 \\
9 \\
11 \\
10 \\
4 \\
3 \\
4\end{array}$ \\
\hline & $\begin{array}{l}\text { 5.5.Ders sürelerine } \\
\text { ilişkin görüşler }\end{array}$ & $\begin{array}{l}\text { 5.5.1. Yeterli } \\
\text { 5.5.2. Yetersiz }\end{array}$ & $\begin{array}{l}13 \\
2\end{array}$ \\
\hline
\end{tabular}

Tablo 6: Uzaktan eğitim ders materyallerine ilişkin genel görüşler

11 katılımcı Muğla Sıtkı Koçman Üniversitesinin uzaktan eğitim sürecinde kullandı̆̆ DYS sistemine yüklenen ders materyallerinden yararlandığını belirtirken, 4 katılımcı ise bu materyallerden yararlanamadığını ifade etmiştir. Katılımcılar öğretim elemanlarının slayt kullanmalarına ilişkin olarak öğretim elemanının slaytları kullanırken bunlara kendinden bir şey katılması, espri yapılması, öğrenciyle etkileşim kurulması, soru sorulması, örneklendirme, benzetme yapılması, farklı programlar kullanılması, video ve film izletilmesi gibi önerilerde bulunmuşlardır. Uzaktan eğitimdeki ders süresi 30 dakika olarak belirlenmiştir. 13 katılımcı bu sürenin öğretim için yeterli olduğunu düşünmekteyken, 2 katılımcı ise yetersiz olduğunu belirtmiştir. Katılımcıların söz konusu görüşlerinden birkaç örnek aşağıda yer almaktadır: 
K2: "Onu ben pek beğenmiyorum slayt okuyarak dersi yapan bir tane hocamız var ve bir saat boyunca sadece slayt okuyor. Aynı tonlama ayn frekans mesela kendisinden hiçbir şey katmıyor. Bu benim için de ve konuştuğum arkadaşlarım için de pekiyi bir şey değil. Slaytı direkt okumak yerine anlatarak dersi yapmasi arada espri yapmasl ya da Chat'ten soru sorduğumuzda onlarl da takip ederek dersi anlatmalı. Mesela soru soruyoruz görmüyor okumuyor. Bizimle iletişim kurarak bizi de derse katarak işlemeli."

K10: "Materyaller yeterliydi gayet ama sadece slaytta odaklanarak ders anlatmak yerine kendinden de bir şeyler katarak ders anlatmaların isterdim. Örnek vererek anlatmalılar. Ben de slayt okuyarak ders anlatabilirim. Bana göre ilişkilendirme yaparak soru cevap yaparak ögrenciyle etkileşime girerek anlatırdım ben olsam. "

K13: "Videolar yapardım. Sanki sınıf ortamındaymışız gibi ilerlemeyi, etkileşimi sağlardım. Tek tarafl bilgi vermektense etkileșimli bir ders yapardım."

K9: "Çok uzun dersler çok sıkıntı çünkü dikkatinizi toplayamıyorsunuz ekran karşısında hareketsizsiniz. 30 ve 40 dakika yeterli bir süre."

Katılımcılar genel olarak sisteme yüklenen materyallerin yeterli olduğunu düşünmelerine karşı, derslerin tek düze olması, öğretmen ve öğretim elemanı etkileşiminin ders sürecinde yeterli düzeyde olmaması ve derslerin slayt dosyalarını okuma biçiminde yürütülmesi nedeniyle verim alamadıklarını belirtmişlerdir.

Aşağıda etkileşim, ölçme ve değerlendirmeye ilişkin genel görüşlerin yer aldığı tema tablolaştırılmıştır:

\begin{tabular}{|c|c|c|c|}
\hline Tema & Kategoriler & Alt kategoriler & \\
\hline \multirow{2}{*}{$\begin{array}{l}\text { TEMA } 6 \text { Öğretim } \\
\text { elemanı ve öğrenci } \\
\text { etkileşimine ilişkin } \\
\text { görüşler }\end{array}$} & $\begin{array}{l}\text { 6.1. interaktif derse } \\
\text { katılım }\end{array}$ & $\begin{array}{l}\text { 6.1.1. Katılabildim } \\
\text { 6.1.2. Katılamadım }\end{array}$ & $\begin{array}{l}6 \\
9\end{array}$ \\
\hline & $\begin{array}{l}\text { 6.2. Sorulara cevap } \\
\text { verebilme }\end{array}$ & $\begin{array}{l}\text { 6.2.1. Cevap verebildim } \\
\text { 6.2.2. Cevap veremedim }\end{array}$ & $\begin{array}{l}6 \\
9\end{array}$ \\
\hline \multirow{5}{*}{$\begin{array}{l}\text { TEMA } 7 \text { Uzaktan } \\
\text { eğitimde ölçme ve } \\
\text { değerlendirmeye } \\
\text { ilişkin görüşler }\end{array}$} & $\begin{array}{l}\text { 7.1.Ödev ve sunum } \\
\text { yapmada sıkıntı çekme }\end{array}$ & $\begin{array}{l}\text { 7.1.1. Sıkıntı çektim } \\
\text { 7.1.2.Sıkıntı çekmedim }\end{array}$ & $\begin{array}{l}6 \\
9\end{array}$ \\
\hline & $\begin{array}{l}\text { 7.2.Ölçme araçlarının } \\
\text { amaca hizmet etmesi }\end{array}$ & $\begin{array}{l}\text { 7.2.1. Amaca hizmet etti } \\
\text { 7.2.2. Amaca hizmet etmedi }\end{array}$ & $\begin{array}{l}5 \\
10\end{array}$ \\
\hline & $\begin{array}{l}\text { 7.3. En çok tercih edilen } \\
\text { ölçme araçları }\end{array}$ & $\begin{array}{l}\text { 7.3.1.Sinav } \\
\text { 7.3.2. Ödev }\end{array}$ & $\begin{array}{l}6 \\
9\end{array}$ \\
\hline & $\begin{array}{l}\text { 7.4. Öğrencinin tercih } \\
\text { edeceği ölçme araçları }\end{array}$ & $\begin{array}{l}\text { 7.4.1. Online sinav } \\
\text { 7.4.2. Ödev }\end{array}$ & $\begin{array}{l}13 \\
2\end{array}$ \\
\hline & $\begin{array}{l}\text { 7.5.Derslerin kolay } \\
\text { geçildiği uygulama }\end{array}$ & 7.5.1.Yüzyüze eğitimde kolay & 1 \\
\hline
\end{tabular}




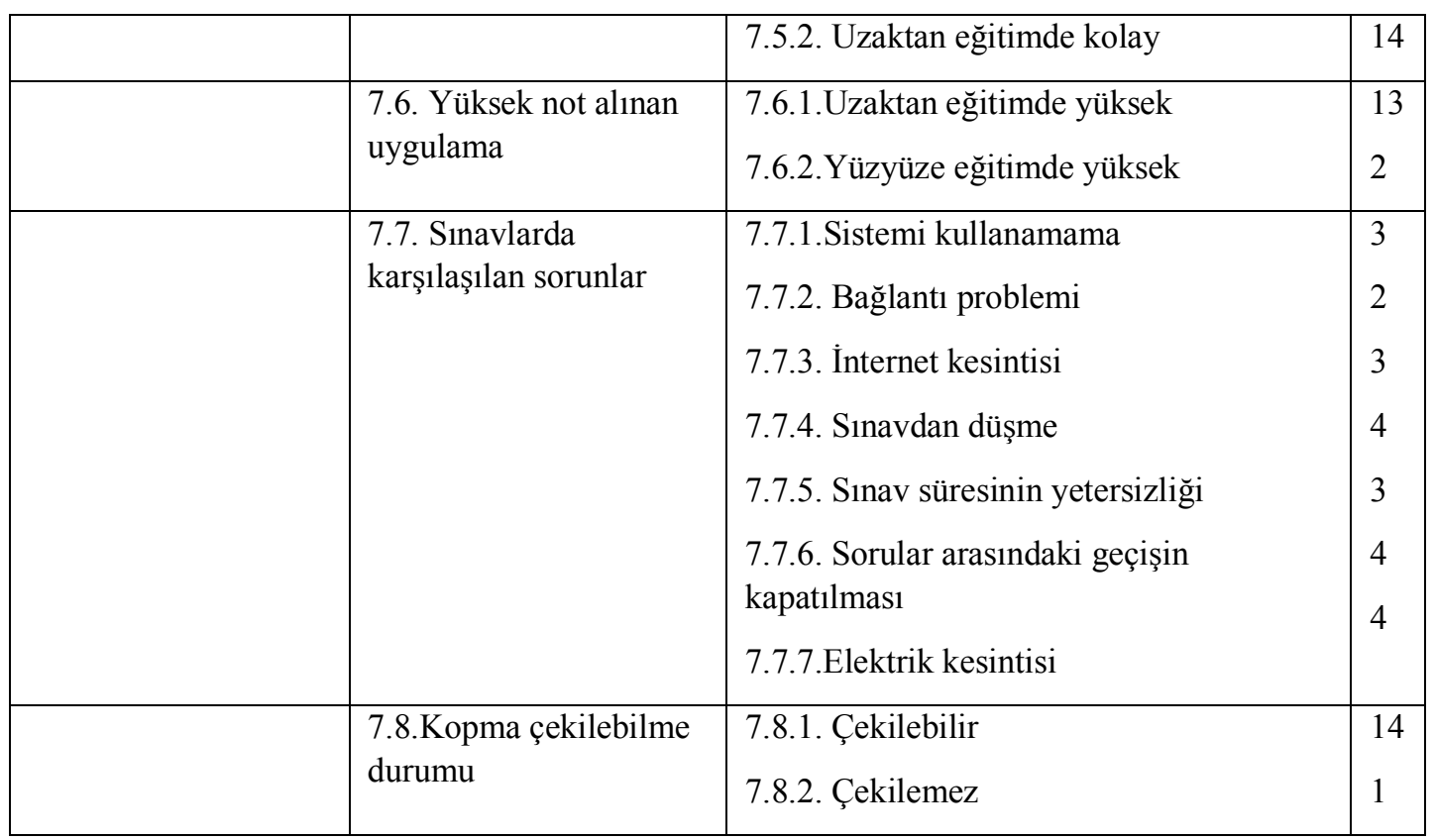

Tablo 7: Etkileşim, Ölçme ve Değerlendirmeye İlişkin Genel Görüşler

6 katılımcı interaktif biçimde derse katılabildiğini, 9 katılımcı ise interaktif olarak derse katılamadığını belirtmiştir. Yine 6 katılımcı sorulan sorulara cevap verebildiğini, 9 katılımcı ise cevap veremediğini dile getirmiştir. Katılımcıların söz konusu görüşlerinden birkaç örnek aşağıda yer almaktadır:

K7: "Benim yazdlğım çoğu şeyi hocalar okumadı ve görmedi. Bu nedenle ben etkileşim kuramadım ve bu beni olumsuz etkiledi. Sorulara cevap veremediğim çok oldu. Çünkü biz düşünelim derken hoca bizi görmediği için cevap vermiyoruz diye geçiyordu."

K11: "Bazı hocalar dersi 2 saat boyunca anlatıyor, sonunda anlamadiğınız var mı diye soruyor. Bu da sıfır etkileşim demek, konuşamadık, sorularımızı soramadık."

Katılımcılar genel olarak ödev ve sunum yapmada sıkıntı çekmemişlerdir. Uzaktan eğitim sürecinde ölçme araçları olarak en çok ödev tercih edilmiştir. Ancak 10 katılımcı kendilerine sunulan ödevlerin amaca hizmet etmediğini, 5 katılımcı ise amaca hizmet ettiğini belirtmiştir. Genel olarak ölçme araçlarının geçerliğinin düşük olduğu anlaşılmaktadır. Dolayısıyla 13 katılımcı online sınav yapılmasını tercih ederken, 2 katılımcı ise sınav yerine ödevler verilmesi gerektiğini belirtmiştir. Katılımcıların söz konusu görüşlerinden birkaç örnek aşağıda yer almaktadır:

K5: "Bazı hocalarımız başarılı sınavlar hazırladı. Ama bazıları iki, üç tane soruyla geçiştirdiler. Biz onca konuya, slaytta çalıştık, bir sürü içerik vardı. Hepsinden sorulmadı. Bir iki soruyla sinav yapan vardı. O konuda çok kötüydü bence."

K7: "Test yapardım ben de ya da konuşma hocası olsaydım 10 dakikalık bir konuşma sınavı yapardım çünkü bu derste konuşamadık."

K11: "Ölçme araçları amaca hizmet etmedi bence. Mesela konuşma dersinin sınavına yazma ödevi verdi hoca bu saçma geldi bana." 
K13: "Sinav olanlar ediyor ama ödevde amaca hizmet etmiyor. Ödevde haklı bir puanlama yapılmıyor. Puanlamada adaletsizlik oluyor."

14 katılımcı uzaktan eğitimde dersleri daha kolay geçtiklerini belirtirken, 1 katılımcı ise yüz yüze eğitimde daha kolay geçtiğini ifade etmiştir. Yine 13 katılımcı uzaktan eğitimde yüksek not aldıklarını, 2 katılımcı ise yüz yüze eğitimde yüksek not aldığını dile getirmiştir. 14 katılımcı uzaktan eğitimde yapılan sınavlarda çok rahat kopya çekilebileceği görüşündeyken, 1 katılımcı ise kopya çekilemeyeceğini belirtmiştir. Sınav esnasında sistemi kullanamama, bağlantı problemi, sınav süresinin yetersizliği, sorular arasındaki geçişin kapatılması, elektrik kesintisi gibi problemlerle karşılaşılmıştır. Katılımcıların söz konusu görüşlerinden birkaç örnek aşağıda yer almaktadır:

K6: "Uzaktan eğitimde derslerden daha kolay geçtim. Ben açıkçası öğretmenlerin de bize toleransl davrandığını düşünüyorum. Sinav esnasında internetim kesildi, diğerinde de kardeşimle aynı anda sinavım vardı. Uzaktan ĕgitimde kopya çekilebilir, örneğin telefondan, gruplardan yapılabilir. Yan sekmeden slaytlara bakılabiliyor."

Yukarıdaki örnek katılımcı ifadelerinden anlaşıldığı gibi uzaktan eğitim sürecinde genel olarak dersten başarılı sayılabilecek kadar yeterli puan anlamada sıkıntı çekilmediği, buna karşın güvenilir bir ölçme ortamının olmadığı da belirtilmiştir.

Aşağıda uzaktan eğitim sürecine ilişkin önerilerin yer aldığ 1 tema tablolaştırılmıştır:

\begin{tabular}{|c|c|c|c|}
\hline Tema & Kategoriler & Alt kategoriler & \\
\hline $\begin{array}{l}\text { TEMA } 8 \text { Uzaktan } \\
\text { eğitim sürecine ilişkin } \\
\text { öneriler }\end{array}$ & 8.1.Günlük hayat & $\begin{array}{l}\text { 8.1.1.Aş1lanma isteği } \\
\text { 8.1.2.Biran önce sosyalleşme }\end{array}$ & $\begin{array}{l}6 \\
9\end{array}$ \\
\hline & 8.2.Eğitim hayatı & $\begin{array}{l}\text { 8.2.1.Yüzyüze eğitime başlama } \\
\text { 8.2.2. Derslerin etkileşimli olması } \\
\text { 8.2.3. Uzaktan eğitim için materyal } \\
\text { geliştirme } \\
\text { 8.2.4. Ders esnasında kameraların açık } \\
\text { olması } \\
\text { 8.2.5. Ara yüzü iyi bir sistemin } \\
\text { geliştirilmesi } \\
\text { 8.2.6.Altyapının iyileştirilmesi } \\
\text { 8.2.7. Devam zorunluluğunun olmaması } \\
\text { 8.2.8. Fırsat eşitliğinin sağlanması } \\
\text { 8.2.9. Yüz yüze eğitimde de bazı } \\
\text { derslerin uzaktan verilmesi }\end{array}$ & $\begin{array}{l}8 \\
10 \\
5 \\
9 \\
5\end{array}$ \\
\hline
\end{tabular}

Tablo 8: Uzaktan eğitim sürecine ilişkin öneriler 
Son olarak katılımcılara bu sürecin günlük hayat ve eğitim hayatına yansımasına ilişkin önerileri sorulmuştur. Günlük hayat bağlamında katılımcılar aşılanmak ve bir an önce sosyalleşmek istediklerini ifade ederlerken, eğitim hayatı açısından ise yüz yüze eğitime başlamanın, derslerin etkileşimli olmasının, uzaktan eğitime ilişkin materyal geliştirilmesinin, ders esnasında kameraların açık olmasının, ara yüzü daha iyi olan bir sistemin geliştirilmesinin, alt yapının iyileştirilmesinin, devam zorunluluğunun kalkmasının, fırsat eşitliğinin sağlanmasının ve yüz yüze eğitime geçildiğinde de bazı derslerin uzaktan verilmesinin gerekliliğini belirtmişlerdir. Katılımcıların söz konusu görüşlerinden birkaç örnek aşağıda yer almaktadır:

K7: "Tabi ki derslerin yüz yüze olmasl. Ama yine online olacaksa da daha çok öğrenciyi sürece dahil edecek şekilde yapılmasını isterim”.

\section{Tartışma ve Sonuç}

Pandemi sürecine bağlı uzaktan eğitimin, Almanca Öğretmenliği lisans programına etkilerinin araştırıldığı bu çalışmadaki bulgular 8 tema altında kategorilendirilmiştir. Genel olarak bu sürecin günlük yaşama ve eğitim hayatına olumsuz etkilerinin daha fazla olduğu anlaşılmaktadır. Bu bulgulardan Almanca Öğretmenliği programındaki alan derslerinin uzaktan eğitime uygun olmadığ becerisini geliştirmede yeterli olmadığı, ancak uzaktan eğitim sürecinin az da olsa alıcı becerileri geliştirdiği, üretimsel becerileri ise geliştirmediği, teorik derslerden verim alındığı, ancak etkin katılım gerektiren uygulamalı derslerin uzaktan eğitime uygun olmadığı sonucuna ulaşılmıştır. Katılımcıların teknolojik yeterliklerine ilişkin görüşleri ise genel olarak olumlu yöndedir. Nitekim Karaman (2018) bilgisayar öz yeterlik algılarına ilişkin farklı katılımcılarla gerçekleştirdiği çalışmasında Almanca öğretmen adaylarının bilgisayar öz yeterlik algılarının orta düzeyde olduğunu ortaya koymuştur. Pandemi sürecinde uzaktan eğitim çalışmalarına ilişkin Kastamonu Üniversitesi kapsamında yapılan çalışmada uzaktan eğitim yönteminde teorik derslerin yüz yüze eğitimde olduğu gibi işlendiğini, uygulamalı derslerde ise verimli bir öğrenme ortamının olmadığı sonucuna ulaşılmıştır (Tarlakazan / Tarlakazan 2020: 3121).

Çalışmadan elde edilen veriler doğrultusunda uzaktan eğitimde kullanılan materyallerin öğrencilerin konuyu anlamaları için yeterli düzeyde olmadığı, katılımcıların sadece slaytlara bağlı ders işleyen öğretim elemanlarının derslerini tek yönlü, sıkıc1, eğitsel yönden verimsiz buldukları ve öğretim sürecinin etkileşimli şekilde yürütülmediği anlaşılmaktadır. Yapılan araştırmada, gelişen teknolojik alt yapıların ve donanımların etkileşimli öğrenme ortamlarının yerini tutamadığı sonucuna ulaşılmaktadır. Pandemi sürecinden önce yapılan birçok çalışmada uzaktan eğitimin avantajları çıkarılmasına karşın (Bozavlı 2017; Fırat 2016; Genç İlter 2009; Hanbay 2013; Hofmann 2002; Kartal 2005; Karaman 2019), pandemi sürecinde yürütülen uzaktan eğitim çalışmalarında (Genç / Gümrükçüoğlu 2020; Ak vd. 2020; Türkmen vd. 2020; Can 2020) uzaktan eğitimin alışılmış öğrenme ortamlarının yerini tutamadığ anlaşılmıştır. Uzaktan eğitimde Almanca öğretimindeki aksaklıkların betimlenmesi ve 
çözüm önerilerinin sunulmasının incelendiği bu çalışmada da uzaktan eğitimin yabancı dil öğretimi için uygun olmadığı sonucuna ulaşılmıştır. ${ }^{1}$

Katılımcıların Youtube'dan konu anlatımını izleyerek, videoları tekrar izleyerek, Google'dan araştırarak, Almanca dizi veya film izleyerek, başka üniversitelerden ders notları alarak uzaktan eğitim sürecini destekledikleri belirlenmiştir. Yaş faktörü ve teknolojik aletlere ilişkin yetkinliğe bağlı olarak yüz yüze eğitimde iyi bir başarı gösteren bir öğretim üyesi, uzaktan eğitim yönteminde aynı başarıyı gösteremeyebilir (Yılmaz Altuntaş 2020: 12). Nitekim bu süreçte birçok öğretim elemanı çevrimiçi nasıl ders vereceğini ve ders materyali hazırlama konusunda sistematik eğitim almadıkları için ders materyalleri ve sunum standartları tutarsız olmuştur (Ak vd. 2020: 903).

Muğla Sitkı Koçman Üniversitesinin uzaktan eğitim sürecinde kullandığ1 DYS sistemine yüklenen ders materyallerinden genel olarak katılımcıların yararlandığ anlaşılmaktadır. Ancak bu materyaller öğrencilerin konuyu anlamaları için yeterli düzeyde değildir. Katılımcılar öğretim elemanlarının sadece slaytlara bağlı ders anlattıklarını belirterek tek yönlü, sıkıcı, eğitsel değeri olmayan bir öğretim sürecinin yaşandığını vurgulamışlardır. Genel olarak etkileşimli bir öğretim sürecinin olmadığı anlaşılmaktadır. Katılımcılara göre 30 dakikalık ders süresinin yeterli olduğu; yüz yüze eğitimde olduğu gibi 50 dakikalık bir sürenin öğrencinin dikkatinin dağılmasına neden olacağ 1 ifade edilmiştir. Türkmen ve diğerleri (2020) tarafından yapılan araştırmada öğrencilerin internet ortamında öğrenmeye ilgilerinin düşük olduğu sonucuna ulaşılmıştır. Can (2020: 36) uzaktan eğitimde canlı derslere katılım ve ders videolarını izleme oranlarının düşük olduğunu belirtmiştir. Öğrencilerin sosyo-ekonomik durumları derslere katılım üzerinde etkili olmuştur. Nitekim kendine ait bilgisayarı ve interneti olmayan öğrenciler dersleri takip edememişlerdir. Teknolojik olanaklara erişimin her kitleye eşit dereceye ulaşamaması dijital uçurum olarak adlandırılan başka bir sorunu da ortaya çıkarmaktadır (Sezgin / Furat 2020: 38).

Uzaktan eğitim sürecinin öz düzenleme ve öz disiplin becerisini geliştirirken, eleştirel düşünme becerisine katkı sağlamadığı sonucuna ulaşılmıştır. Sonuç olarak uzaktan eğitimin öğrencinin bilişsel ve duyuşsal gelişimi üzerinde olumlu etkilerinin olduğu söylenemez. Eleştirel düşünmeyle birey yaşadığı anı sorgulama sürecine girerek zihin şemalarında bir denge oluşur ve bunun sonucunda da bilginin zihinde işlenmesi süreci meydana gelir (Erdem 2020: 3f). Dolayısıyla eleştirel düşünmenin öğrenme sürecine katkısı dikkate alındığında uzaktan eğitim sürecinin bu beceriyi olumsuz etkilediği söylenebilir.

Uzaktan eğitim sürecinde ölçme araçları olarak en çok ödev tercih edilmiştir. Genel olarak ölçme araçlarının geçerliğinin düşük olduğu anlaşılmaktadır. Katılımcıların uzaktan eğitim döneminde derslerden daha kolay geçtikleri ve daha yüksek not aldıkları, uzaktan eğitimde yapılan sınavlarda çok rahat kopya çekilebildiği ifade edilmiştir. İlahiyat fakültesi öğrencilerinin uzaktan eğitim sürecine ilişkin

1 Ancak İstanbul Üniversitesi uzaktan eğitim uygulamalarını değerlendiren çalışmada öğrenciler tarafindan öğretim materyallerinin nitelikli ve çeşitli olduğu sonucu elde edilmiş bunun yanı sıra canlı ders anlatımları da yeterli bulunmuştur (Ak vd. 2020: 33). 
görüşlerinin araştırıldığı çalışmada öğrencilerin büyük bir bölümü uzaktan eğitimden memnun olmadıklarını belirtmişlerdir. Yine bu çalışmada ölçme ve değerlendirme sürecinde güvenilir ölçme ve değerlendirme yapılamadığı sonucuna ulaşılmıştır (Genç / Gümrükçüoğlu 2020: 411).

Uzaktan eğitim sürecine ilişkin olumlu görüşler ise aileyle daha çok zaman geçirme, öğrenciye çok zaman kalması, kendine zaman ayırabilme, yorucu olmaması, ekonomik, zaman kısıtlamasının olmaması, arkadaşlarından not isteme sıkıntısının olmaması, mekân sınırının olmaması olarak belirlenmiştir. Uzaktan eğitim sürecinde ders saatleri sürelerinin kısaltılması ve öğrencilerin sınıf ortamında bulunma zorunluluğunun olmaması, kendilerine ve ailelerine daha fazla zaman ayırmalarına olanak vererek öğrencilerin gerek kendilerine gerek ailelerine ilişkin farkındalıklarını arttıran bir etmendir. Bunun yanı sıra üniversitelerinin bulunduğu şehirlerde ev kirası veya yurt ücreti vermek zorunda kalmamaları nedeniyle bu sürecin ekonomik olarak da ögrencilere katkı sağladığı söylenebilir.

Katılımcılar aşılanmayı, sosyalleşmeyi, yüz yüze eğitime başlamayı, derslerin etkileşimli olmasını, uzaktan eğitime ilişkin materyal geliştirilmesini, ders esnasında kameraların açık olmasını, alt yapının iyileştirilmesini, fırsat eşitliğinin sağlanmasını ve yüz yüze eğitime geçildiğinde de bazı derslerin uzaktan verilmesini dilemişlerdir. Katılımcıların uzaktan eğitim sürecine ilişkin öneri ve dilekleri incelendiğinde genel olarak bu süreçten çok da memnun olmadıkları, alışılagelmiş sınıf ortamında kendileri için yüz yüze derslerin daha verimli olduğu, uzaktan eğitimde öğretim elemanı ve öğrenci etkileşiminin eksik kaldığı biçiminde değerlendirme yapılabilir. Genel anlamda yabancı dil öğretimi, özel anlamda ise Almanca öğretimi açısından uzaktan eğitim sürecinde, etkinliklere bağlı öğrenci katılımının ön planda ve temelinde beceri öğretiminin olduğu bir alan olması nedeniyle beklenen kazanımların öğrenciye verildiğini söylemek mümkün olmamıştır. Çünkü Almanca öğretiminde rehber görevindeki bir öğretmenin gözetiminde yazma ve konuşma gibi uygulama gerektiren öğrenme alanları bulunmaktadır. Almanca öğretiminde teorik derslerde olduğu gibi bilgi düzeyindeki içeriklerin aktarılması yerine kavrama ve uygulama gibi üst düzey kazanımların aktarılması gerekmektedir. Öğrencide bu kazanımların ediniminin gerçekleşip gerçekleşmediği ise öğrencilerin aktif katılımını gerektiren etkinliklerin ön planda olduğu sınıf ortamında öğrencilerin hazırladığı ürünlerin nitelikleri incelenerek ölçülebilmektedir. Dolayısıyla Almanca öğretiminde öğrenci ve öğretmen arasındaki etkileşim bu bağlamda daha da önem arz etmektedir. Ders sürecinde öğrenci öğretmen arasındaki bilgi alışverişi, soru sorma ve anında dönüt alma Almanca öğretimini destekleyen bir durum olmasına karşın uzaktan eğitim sürecinde öğrencilere bu imkân sağlanamamıştır. Çünkü soyut olan dil bilgisel yapıların öğrencilere kazandırılmasında kullanım ortamı sağlanamamıştır ve bu yapıları öğrenciler kural boyutundan kalıp uygulama aşamasına taşıyamamışlardır. 


\section{Öneriler}

Çalışmada elde edilen sonuçlara göre Almanca öğretmenliği lisans programındaki derslerin uzaktan eğitime uygun olmadığı sonucuna bağlı olarak Almanca öğretimi gibi uygulamaya dayalı ve beceri ögretiminin ön planda olduğu derslere yönelik olarak uzaktan eğitimin yapısına uygun dijital içerikler ve öğrenci katılımının mümkün olabileceği daha kapsamlı ara yüzler geliştirilmelidir. Araştırmada katılımcılar öğretim elemanlarının uzaktan eğitim sisteminin gerektirdiği teknolojiyi kullanma yeterliğine sahip olmadıklarını belirtmeleri nedeniyle öğretim elemanlarına bu teknolojileri kullanabilmelerine ilişkin eğitim verilmesinin bu problemi çözebileceği düşünülmektedir. Pandemi sürecinde öğrencilerin toplu biçimde barınmalarının mümkün olmaması nedeniyle her bölüm ölçme ve değerlendirmenin yüz yüze uygulanabilirliğini mümkün hale getirememiştir. Harmanlanmış eğitim kapsamında ölçme ve değerlendirmenin güvenirliğini sağlamak için sınavların yüz yüze yapılabileceği uygun ortam sağlanmalıdır. Bu süreç öğretim elemanları ve öğrenci açısından iki türlü ele alınmalıdır. Çünkü öğretim üyeleri de alışı olmadıkları bir yöntem olan uzaktan eğitim yöntemi ile derslerini yürütmek durumunda kalmışlardır. Verimliliği arttırmak amacıyla uzaktan eğitime uygun ders materyalleri hazırlanmalıdır. Uzaktan eğitiminin yapısına uygun olan dijital içerikler oluşturulmalıdır. Uzaktan eğitimdeki en büyük engel olan firsat eşitsizliğinin en aza indirilebilmesi için de alt yapı çalışmaları, teknolojik donanım gibi uzaktan eğitimde temel olan unsurlar desteklenmelidir. Öğrencilerin aktif olarak derse katılabileceği uzaktan eğitim programları geliştirilmelidir.

\section{Kaynakça}

Ak, Mahmut vd. (2020): Kovid-19 Küresel Salgın Sürecinde İstanbul Üniversitesi Uzaktan Eğitim Uygulamalarına Genel Bir Bakış. İstanbul Üniversitesi Sosyoloji Dergisi. 40(2),1-41.

Bozavlı, Ebubekir (2017): Yeni Teknolojiler Işı̆̆ında Eğitim Aktörlerinin Yabancı Dil Öğretiminde Sanal Sınıf Algıları. Atatürk Üniversitesi Sosyal Bilimler Enstitüsü Dergisi. 21(1), 347-358.

Bozkurt, Aras (2020): Koronavirüs (Covid-19) Pandemi Süreci ve Pandemi Sonrası Dünyada Eğitime Yönelik Değerlendirmeler: Yeni Normal ve Yeni Eğitim Paradigması. AUAd. 6(3), 112-142.

Büyüköztürk, Şener vd. (2013): Bilimsel Araştırma Yöntemleri. 15. B. Ankara: Pegem Akademi.

Can, Ertuğ (2020): Coronavirüs (Covid-19) pandemisi ve pedagojik yansımaları: Türkiye'de açık ve uzaktan eğitim uygulamaları. Açıöğretim Uygulamaları ve Araştırmaları Dergisi. 6(2),11-53.

Erdem, Mukaddes (2020): Düşünme - Akıl Yürütme. Erdem Mukaddes / Sarsar Firat (Ed.): Dijital Teknoloji Aracılı Düşünme Öğretimi. Ankara: Pegem Akademi, 3-53.

Fırat, Mehmet (2016): 21.Yüzyılda Uzaktan Öğretimde Paradigma Değişimi. Yüksek Öğretim ve Bilim Dergisi. 6(2),142-150.

Genç, Mustafa F. / Gümrükçüoğlu, Süleyman (2020): Koronavirüs (Covid-19) sürecinde ilahiyat fakültesi öğrencilerinin uzaktan eğitime bakışları. Turkish Studies. 15(4), 403-422.

Genç İlter, Binnur (2009): Effect of Technology on Motivation in EFL Classrooms. Turkish Online Journal of Distance Education-TOJDE. 10 (4), 136-158. 
Hanbay, Orhan (2013): Relationship Between Web-Based Learning Time Outside The Classroom and Academic Achievement In German As a Tertiary Language By The Students On Vocational High Schools. Turkish Online Journal Of Distance Education - TOJDE. 14 (1), 29-34.

Hofmann, Donald W. (2002): Internet-Based Distance Learning in Higher Education. Tech directions. 62(1), 28-32.

Kartal, Erdoğan (2005): Çoklu-Ortamlı Yazılımların Fransızcanın Yabancı Dil Olarak Öğretimindeki Yeri ve İşlevi. Uludağ Üniversitesi, Eğitim Fakültesi Dergisi XVIII. 2, 231-244.

Karaman, Fatma (2019): Evde Ders Okulda Ödev Modelinin İkinci Yabancı Dil Olarak Almanca Dilbilgisinin Öğretimine Uyarlama. Duman, Bilal / Sidekl, Sabri (Ed.): Eğitimde Araştırmalar. Ankara: Eğiten Kitap Yayıncılık, 135-147.

Karaman, Fatma (2018): Computer Sufficiency Perceptions of German Language Teacher Candidates. Social Sciences Studies Journal. 4(22), 3973-3979.

Miles, Matthew B. / Huberman, A. Michael (1994): Qualitative data analysis: An expanded sourcebook 2nd ed. Thousand Oaks, CA, US: Sage Publications.

Milli Eğitim Bakanlığı (2006): Milli Eğitim Bakanlığı Yabancı Dil Eğitimi Ve Öğretimi Yönetmeliği, http://mevzuat.meb.gov.tr/html/26184_1.html (Son Erişim Tarihi: 23.01.2021).

Özalkan, Gizem Şükran (2021): Uzaktan Eğitimde Ölçme ve Değerlendirme: Pandemi Sürecinde Sosyal Bilimler Eğitimini Yeniden Düşünmek. IJEASS. 4, 18-26.

Sarı, Halil İbrahim (2020): Evde Kal Döneminde Uzaktan Eğitim: Ölçme ve Değerlendirmeyi Neden Karantinaya Almamalıyız?. Uluslararası Eğitim Araştırmacıları Dergisi. 3(1), 121-128.

Sezgin, Sedef / Fırat, Mehmet (2020): Covid-19 pandemisinde uzaktan eğitime geçiş ve dijital uçurum Tehlikesi. Açıköğretim Uygulamaları ve Araştırmaları Dergisi. 6(4), 37-54.

Tarlakazan, Elif / Tarlakazan, Burak Erhan (2020): Covid 19 pandemi sürecinde Türkiye'de uzaktan eğitim çalışmaları: Kastamonu Üniversitesi Örneği. Turkish Studies. 15(7), 3107-3122.

Telli Yamamoto, Gonca / Altun, Deniz (2020): Coronavirüs ve Çevrimiçi (Online) Eğitimin Önlenemeyen Yükselişi. Üniversite Araştırmaları Dergisi. 3(1), 25-34.

Türkmen, Burcu vd. (2020): Covid-19 Sosyal İzolasyon Döneminde Meslek Yüksekokulu Öğrencilerinin E- Öğrenmeye Hazırbulunuşluk Düzeylerinin İncelenmesi: Çaycuma Meslek Yüksekokulu Örneği. Uluslararası Sosyal Araştırmalar Dergisi. 13(72), 690-700.

Yıldırım, Ali / Şimşek, Hasan (2018): Sosyal Bilimlerde Nitel Araştırma Yöntemleri, 11. Baskı, Ankara: Seçkin Yayıncılık.

Yılmaz Altuntaş, Elgiz vd. (2020): Covid-19 Pandemisi Sürecinde Üniversite Öğrencilerinin Yükseköğretim Kurumlarının Uzaktan Eğitime Yönelik Stratejilerine ve Öğrenme Deneyimlerine İlişkin Algı Düzeyleri. Uluslararası Halkla İlişkiler ve Reklam Çalışmaları Dergisi. 3(2), 8-23. 